\title{
UJI KARAKTERISTIK FISIS, pH DAN ORGANOLEPTIK PADA MINYAK JELANTAH DENGAN PENAMBAHAN BUAH MENGKUDU (Morinda citrifolia)
}

\author{
Misrawati, Sri Fitria Retnowaty, Yulia Fitri \\ Program Studi Fisika, FMIPA dan Kesehatan Universitas Muhammadiyah Riau
}

Email:misrawatyyy@gmail.com

\begin{abstract}
ABSTRAK
Minyak goreng merupakan salah satu bahan pangan yang sangat dibutuhkan oleh seluruh lapisan masyarakat. Meningkatnya harga minyak goreng dikalangan masyarakat dengan perekonomian rendah, merupakan salah satu faktor penyebab pemakaian minyak goreng berulang kali (minyak jelantah). Penggunaan minyak jelantah secara berulang kali dapat membahayakan kesehatan, seperti keracunan, diare, pengendapan lemak dalam pembuluh darah, kanker dan lain-lain. Telah dilakukan penelitian uji karakteristik fisis, $\mathrm{pH}$ dan organoleptik pada minyak jelantah dengan penambahan buah mengkudu blender dan potong. Parameter yang diukur adalah uji fisis (viskositas, massa jenis, ORP, konduktivitas listrik, resistivitas), $\mathrm{pH}$ dan organoleptik (bau dan rasa). Hasil penelitian yang telah dilakukan untuk uji fisis pada minyak jelantah yang ditambah mengkudu potong dan blender, memiliki karakteristik fisis yang tidak jauh berbeda. Akan tetapi, untuk uji $\mathrm{pH}$ terdapat satu jenis sampel, penambahan buah mengkudu potong dengan massa 75 gram memiliki nilai $\mathrm{pH}$ yang lebih tinggi dari pada sampel minyak murni dan sampel minyak jelantah, mungkin disebabkan oleh pengaruh suhu pada saat pengambilan sampel. Untuk hasil uji organoleptik, minyak jelantah yang ditambahkan dengan mengkudu potong cenderung lebih disukai dari pada mengkudu blender.
\end{abstract}

Kata kunci: Minyak jelantah, antioksidan, buah mengkudu

\section{PENDAHULUAN}

Minyak goreng merupakan salah satu kebutuhan pokok manusia, yang dikonsumsi oleh seluruh lapisan masyarakat. Pada umumnya minyak goreng digunakan sebagai media menggoreng bahan pangan dan dapat menambah cita rasa. Dalam proses penggorengan, minyak goreng berperan sebagai media untuk perpindahan panas, yang cara kerjanya sangat efisien dan merata pada bahan yang digoreng [1].

Meningkatnya harga minyak goreng dikalangan masyarakat yang memiliki perekonomian rendah, merupakan salah satu faktor pemicu adanya pemakaian minyak goreng secara berulang kali (minyak jelantah). Minyak jelantah adalah minyak goreng yang telah dipakai berulang kali sehingga warnanya menjadi gelap dan kehitaman. Penggunaan minyak goreng secara berulang-ulang dengan suhu tinggi akan menyebabkan minyak goreng menjadi rusak. Hal ini disebabkan banyaknya kotoran, senyawa- senyawa asam karboksilat bebas yang berasal dari penggorengan sebelumnya, dan warna minyak goreng semakin tidak jernih, serta terjadinya reaksi degradasi yang dapat menurunkan kualitas minyak [3]. Apabila mengkonsumsi minyak jelantah dalam jumlah yang banyak akan membahayakan kesehatan seperti keracunan dan diare. Selain itu, apabila mengkonsumsi minyak jelantah dalam jangka waktu yang lama akan menyebabkan pengendapan lemak dalam pembuluh darah, kanker dan lain-lain [2].

Penggunaan minyak jelantah tidak dianjurkan untuk dikonsumsi kembali. Dari uraian di atas, maka penulis perlu melakukan penelitian tentang uji karakteristik fisis, $\mathrm{pH}$ dan organoleptik pada minyak jelantah menggunakan buah mengkudu. Beberapa peneliti telah melakukan penelitian tentang pemurnian minyak jelantah diantaranya menggunakan arang aktif sabut kelapa, penetralan dan adsorbsi, penambahan asam sitrat, dan arang aktif dari ampas tebu [1, 2, 3, 4]. Hasilnya cukup 
efektif dalam pemurnian minyak jelantah. Dalam penelitian ini untuk uji karakteristik fisis, $\mathrm{pH}$ dan organoleptik pada minyak jelantah penulis menggunakan buah mengkudu. Buah ini digunakan karena mudah dijumpai di daerah tempat penulis dan harganya murah. Selain itu buah mengkudu merupakan salah satu sumber antioksidan yang dapat menetralisir senyawasenyawa radikal bebas, mengandung zat antiseptik, zat antikanker, antioksidan (xeronin, proxeronin, asam askorbat) dan zat-zat lainnya [5].

Penelitian ini bertujuan untuk mengetahui karakteristik fisis, $\mathrm{pH}$ dan Organoleptik dari minyak jelantah yang ditambahkan buah mengkudu blender dan potong.

\section{METODOLOGI PENELITIAN}

\section{Alat}

Dalam penelitian uji karakteristik fisis, $\mathrm{pH}$ dan organoleptik pada minyak jelantah menggunakan buah mengkudu, alat yang digunakan adalah alat pengukur $\mathrm{pH}$, ORP, konduktivitas listrik, resistivitas, viskometer Ostwald, gelas ukur, pipet tetes, botol sampel, blender, timbangan dan perlengkapan dapur (kompor gas, wajan, sendok, piring, saringan).

\section{Bahan}

Adapun bahan dalam Penelitian ini adalah:

1. Minyak jelantah dari penggorengan ikan sebanyak $250 \mathrm{ml} / \mathrm{sampel}$

2. Variasi massa buah mengkudu yaitu 25 gram, 50 gram, dan 75 gram.

\section{Prosedur Kerja}

Minyak jelantah sebanyak $250 \mathrm{ml} / \mathrm{sampel}$ ditambahkan buah mengkudu yang dipotong dan diblender sebanyak 25 gram, 50 gram, dan 750 gram. Diamkan minyak jelantah yang telah ditambahkan buah mengkudu selama 15 menit, kemudian dipanaskan. Minyak yang telah dipanaskan disaring dan dianalisa sifat fisis, $\mathrm{pH}$, dan organoleptiknya. Hal yang sama juga dilakukan untuk sampel minyak jelantah yang tidak ditambah buah mengkudu (MJ) dan minyak murni.

\section{Pembuatan minyak jelantah}

1. Minyak murni (kemasan) sebanyak $2 \mathrm{Kg}$.
2. Ikan $1 \mathrm{Kg}$ dibagi menjadi 4 bagian $(1 / 4 \mathrm{Kg})$

3. Ikan sebanyak $1 / 4$ bagian pertama digoreng dengan minyak $2 \mathrm{Kg}$, kemudian angkat ikan yang telah matang.

4. Ikan 1/4 bagian kedua digoreng dengan minyak yang sama dan angkat ikan yang telah matang, kemudian lakukan penggorengan untuk 1/4 bagian yang ketiga dan keempat.

5. Minyak jelantah dari penggorengan ikan didiamkan selama 5 menit, kemudian ditimbang sebanyak $250 \mathrm{ml} /$ sampel.

6. Kemudian minyak jelantah ditambahkan buah mengkudu dengan variasi potong dan blender.

\section{Uji Fisis}

\section{Uji Viskositas}

Untuk mengukur nilai viskositas sampel digunakan viskometer ostwald.

Cara Kerja:

Sampel dimasukkan kedalam viskometer ostwald, dan sampel akan terhisap oleh pompa sampai diatas tanda a, kemudian sampel dibiarkan mengalir kebawah (b), waktu yang diperlukan dari a ke $\mathrm{b}$ ditulis dan dihitung menggunakan stopwatch [13], kemudian hitung viskositas menggunakan persamaan (2.1). Pengambilan data ini dilakukan 3 kali pengulangan pada setiap sampel.

\section{Massa Jenis}

Cara kerja untuk mengukur massa jenis adalah timbang massa gelas ukur (kosong), kemudian masukkan minyak jelantah sebanyak $25 \mathrm{ml}$ kedalam gelas ukur dan ditimbang. Maka massa dari minyak (sampel) adalah massa gelas ditambah minyak dikurang dengan massa gelas kosong. Volume minyak adalah $25 \mathrm{ml}$. Kemudian massa jenis sampel dihitung menggunakan persaman (2.2). Metode ini dilakukan 3 kali pengulangan pada setiap sampel.

\section{Uji ORP}

Pengukuran ORP sampel dilakukan dengan mencelupkan alat (ORP) ke dalam sampel. Nilai ORP sampel akan terbaca di layar alat. Pengambilan data ini dilakukan 3 kali pengulangan pada setiap sampel. 


\section{Uji Konduktivitas Listrik}

Pengukuran konduktivitas listrik sampel dilakukan dengan mencelupkan alat (konduktivitas listrik) ke dalam sampel. Nilai konduktivitas listrik sampel akan terbaca di layar alat. Metode ini dilakukan 3 kali pengulangan pada setiap sampel.

\section{Uji Resistivitas}

Pengukuran resistivitas sampel dilakukan dengan mencelupkan alat (resistivitas) ke dalam sampel. Nilai resistivitas sampel akan terbaca di layar alat. Metode ini dilakukan 3 kali pengulangan pada setiap sampel.

\section{Uji pH}

Pengukuran $\mathrm{pH}$ sampel dilakukan dengan mencelupkan alat ( $\mathrm{pH}$ meter) ke dalam sampel. Nilai pH sampel akan terbaca di layar alat. Pengambilan data ini dilakukan 3 kali pengulangan pada setiap sampel.

\section{Uji Organoleptik (bau dan rasa)}

Uji kesukaan pada bau dan rasa dilakukan berdasarkan tingkat kesukaan panelis (Tabel 1). Uji organoleptik ini akan menggunakan 10 orang panelis. Panelis ditentukan berusia 30 - 40 tahun dan berjenis kelamin perempuan.

Tabel. 1. Uji Organoleptik Penelitian

\begin{tabular}{cc}
\multicolumn{2}{c}{ Tabel. 1. Uji Organoleptik Penelitian } \\
\hline PENERIMAAN & NILAI \\
\hline SUKA & 3 \\
NETRAL & 2 \\
TIDAK SUKA & 1 \\
\hline
\end{tabular}

3. HASIL DAN PEMBAHASAN Viskositas

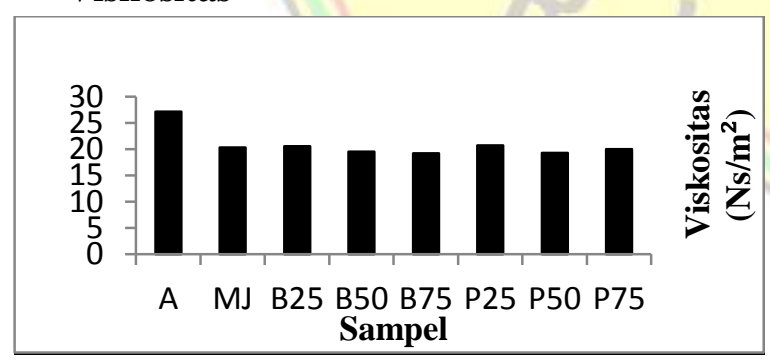

Gambar. 1. Viskositas minyak goreng

Berdasarkan Gambar 1 nilai viskositas minyak murni pada sampel A lebih tinggi dibandingkan dengan sampel minyak jelantah baik yang belum ditambahkan buah mengkudu. Hal ini mungkin terjadi karena pada sampel A belum dipakai, sehingga kerapatan pada minyak tersebut belum berkurang, sehingga nilai viskositas lebih tinggi dibandingkan minyak jelantah. Hal ini sesuai dengan penelitian yang telah dilakukan [13], bahwa minyak goreng yang belum pernah dipakai mempunyai nilai viskositas lebih tinggi dari pada minyak goreng yang telah dipakai berulang kali. Kerapatan minyak tersebut berkurang akibat dari pemanasan saat penggorengan [13]. Selain itu, dengan menambah jumlah adonan yang digoreng maka suhu dari minyak juga akan meningkat. Peningkatan suhu karena pemanasan tersebut akan mengakibatkan ikatan antar molekul minyak berkurang sehingga viskositasnya mengecil. Sedangkan viskositas minyak jelantah yang ditambahkan mengkudu blender dan potong dengan berat 25 gram, memiliki nilai viskositas lebih tinggi. Hal demikian terjadi mungkin karena pengaruh suhu pada saat pembuatan sampel. Apabila dibandingkan antara sampel MJ (minyak jelantah) dengan sampel yang diberi penambahan buah mengkudu dipotong dan diblender, terlihat bahwa kecenderung nilai viskositasnya sama.

\section{Massa Jenis}

Berdasarkan Gambar 2 terlihat bahwa nilai massa jenis untuk sampel A (murni), memiliki nilai lebih rendah dibandingkan sampel lainnya, hal demikian disebabkan karena minyak murni belum dipakai. Namun terdapat satu jenis sampel yang memiliki nilai yang hampir mendekati nilai massa jenis minyak murni yaitu sampel P50 (minyak jelantah ditambah 50 gram buah mengkudu potong). Untuk sampel MJ, B25, B50, B75, P25, P75 menunjukkan nilai massa jenis yang lebih tinggi dari pada sampel A (minyak murni). Hal demikian disebabkan karena tekstur buah mengkudu, serta adanya bahan-bahan pengotor yang berasal dari bahan yang digoreng kedalam minyak tersebut [16].

\section{ORP}

Hasil analisis ORP dari minyak jelantah yang tanpa atau ditambahkan buah mengkudu dapat dilihat pada Gambar 3. Untuk nilai ORP pada minyak murni (sampel A) cenderung lebih tinggi dibandingkan dengan sampel minyak jelantah. Hal demikian disebabkan karena minyak murni belum dipakai, sehingga minyak murni memiliki 
kemampuan untuk menjaga kualitas minyak dari bakteri yang dapat membuat minyak tersebut menjadi rusak.

Untuk sampel minyak jelantah, sampel yang ditambahkan buah mengkudu blender dan potong, memiliki kecendrungan nilai sama dengan sampel minyak jelantah. Hal demikian disebabkan karena minyak tersebut sudah dipakai lebih dari 4 kali, dan tekstur buah mengkudu yang belum bisa mengatasi bakteri yang ada didalam minyak tersebut.

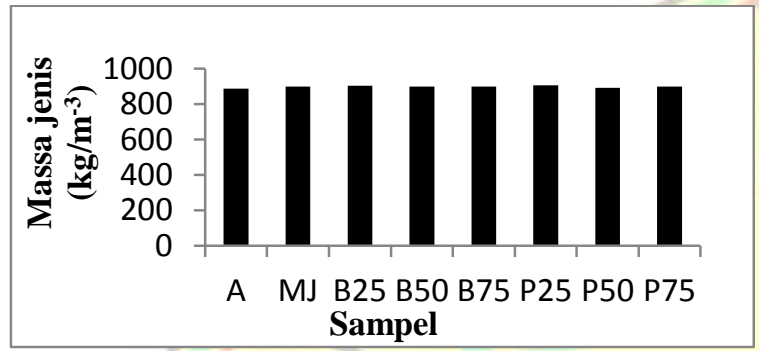

Gambar.2. Massa jenis minyak goreng

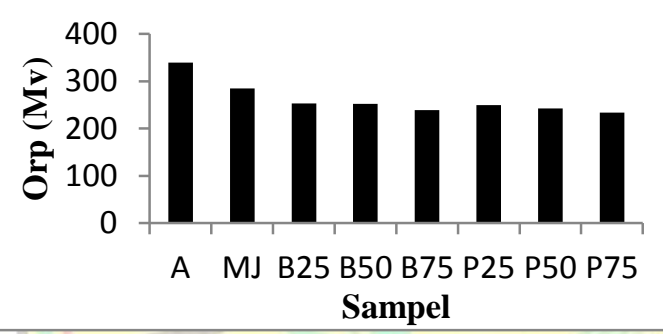

Gambar.3. ORP minyak goreng

\section{Konduktivitas Listrik}

Pada Gambar 4, menunjukkan bahwa nilai konduktivitas untuk setiap sampel cenderung memiliki nilai yang sama. Tetapi pada sampel B50 (minyak jelantah ditambah 50 gram mengkudu blender) dan P50 (minyak jelantah ditambah 50 gram mengkudu blender memiliki nilai konduktivitas listrik tinggi, mungkin disebabkan karena pengaruh suhu pada saat pengambilan sampel dan tekstur dari buah mengkudu yang dapat meningkatnya nilai konduktivitas listrik.

\section{Resistivitas}

Hasil analisis resistivitas dari minyak jelantah yang tanpa atau ditambahkan buah mengkudu dapat dilihat pada Gambar 5. Resistivitas merupakan kebalikan dari konduktivitas listrik, dimana resistivitas merupakan kemampuan untuk menghambat arus listrik. Pada setiap sampel baik sampel A, MJ dan sampel yang diberi penambahan mengkudu diblender dan dipotong, memilik nilai resistivitas yang sama.

\section{pH}

Untuk sampel minyak murni memiliki nilai $\mathrm{pH}$ yang lebih rendah dari pada sampel B50, B75, dan P50. Sedangkan untuk sampel lainnya (MJ, B25, BP25 dan P75) memiliki nilai pH yang lebih tinggi dari minyak murni.

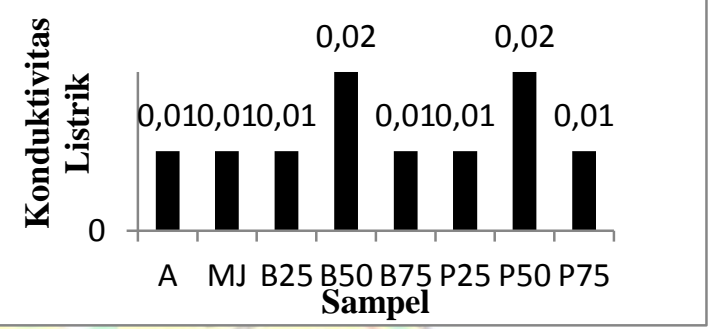

Gambar.4. K. listrik minyak goreng

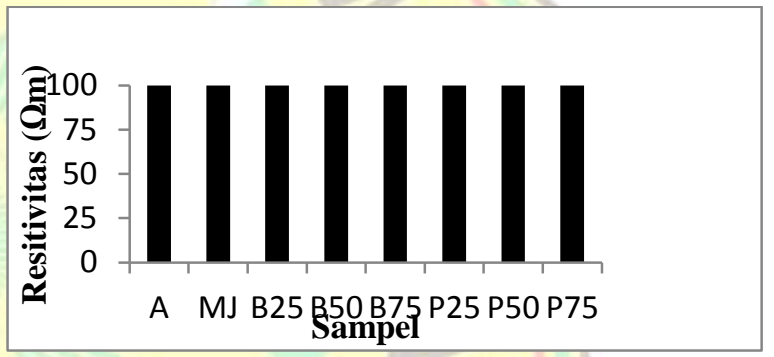

Gambar.5. Resistivitas minyak goreng

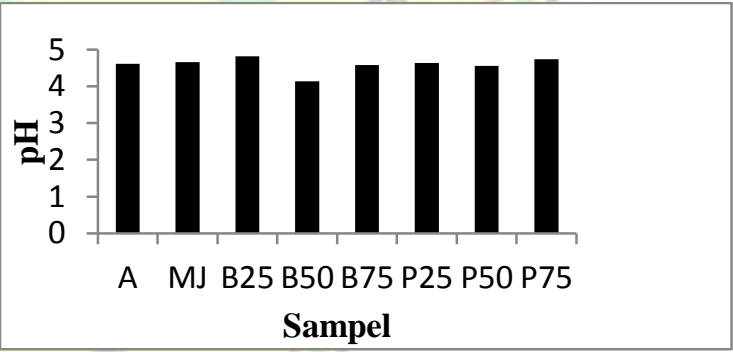

Gambar. 7. pH minyak goreng

Organoleptik

Organoleptik Bau

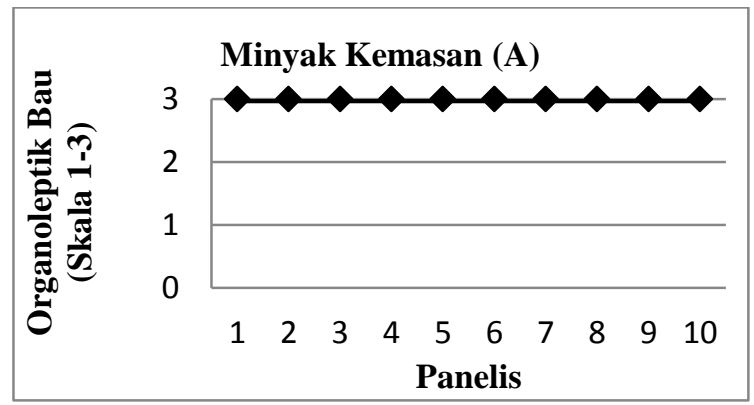

Gambar.6. Organoleptik bau minyak Kemasan 
Uji kesukaan pada organoleptik bau dilakukan berdasarkan tingkat kesukaan 10 orang panelis wanita yang seluruhnya rata-rata berusia 30 sampai 40 tahun dan bertempat tinggal di Tapung Hilir.

Hasil analisis organoleptik bau dapat dilihat pada setiap Gambar 6 terlihat dari 10 panelis, $100 \%$ menyatakan suka untuk sampel minyak murni. Hal demikian disebabkan karena minyak kemasan tersebut belum dipakai.

Untuk Gambar 7 terlihat dari 10 panelis, 20\% menyatakan netral atau biasa dan $80 \%$ menyatakan tidak suka. Terlihat kecendrungan wanita pada usia 30 sampai 40 tahun tidak menyukai bau minyak jelantah.

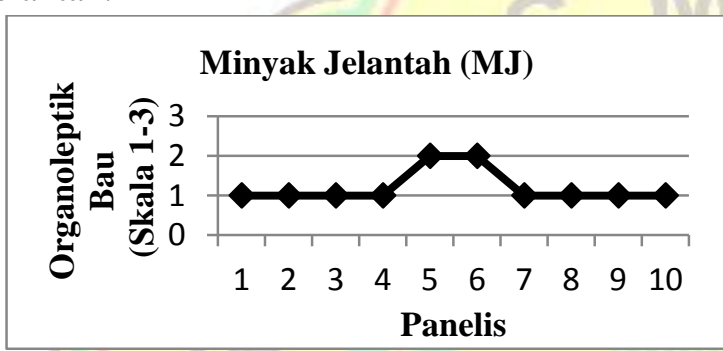

Gambar.7. Organoleptik bau minyak Jelantah

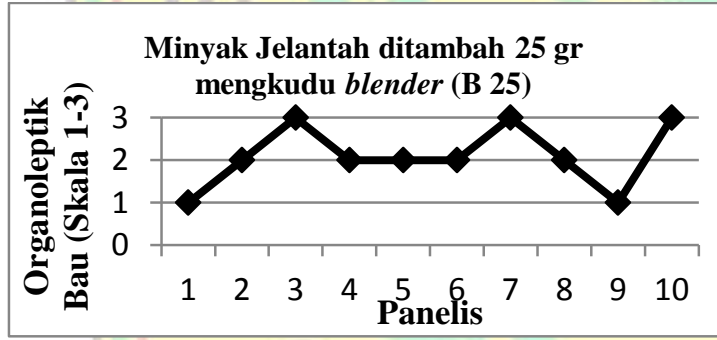

Gambar.8. Organoleptik bau minyak jelantah $+25 \mathrm{gr}$ mengkudu blender

Untuk Gambar 8 terlihat dari 10 panelis, 50\% menyatakan netral atau biasa, 30\% menyatakan suka, dan $20 \%$ menyatakan tidak suka. Terlihat kecendrungan wanita pada usia 30 sampai 40 tahun menyatakan biasa (netral) untuk sampel minyak jelantah yang ditambahkan 25 gram mengkudu blender.

Untuk Gambar 9 terlihat dari 10 panelis, 30\% menyatakan netral atau biasa, 50\% menyatakan suka dan $20 \%$ menyatakan tidak suka. Terlihat kecendrungan wanita pada usia 30 sampai 40 tahun menyukai sampel minyak jelantah yang ditambahkan 50 gram mengkudu blender.

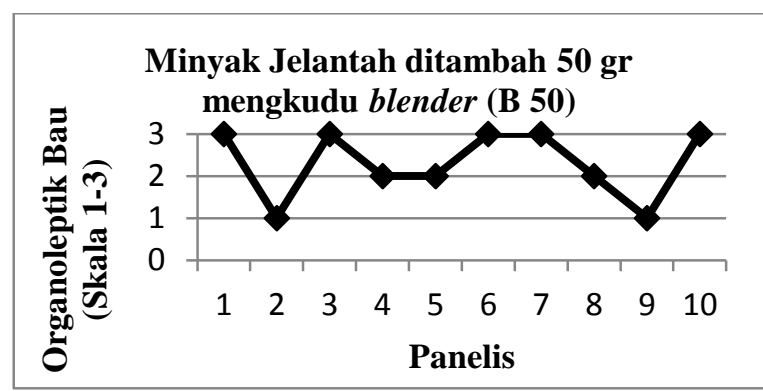

Gambar.9. Organoleptik bau minyak jelantah +50 gr mengkudu blender

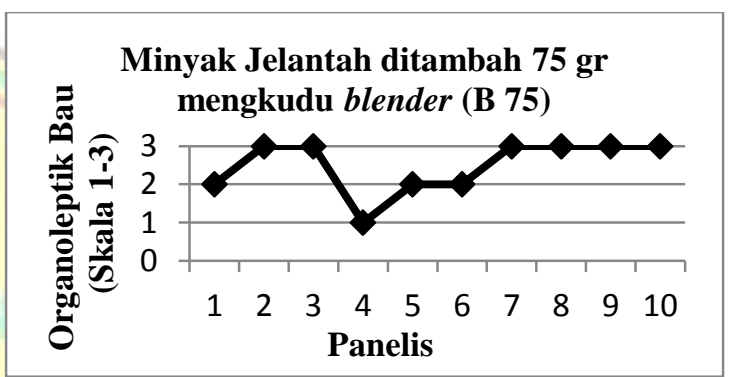

Gambar.10. Organoleptik bau minyak jelantah +75 gr mengkudu blender

Untuk Gambar 10 terlihat dari 10 panelis, 30\% menyatakan netral atau biasa, $60 \%$ menyatakan suka dan $10 \%$ menyatakan tidak suka. Terlihat kecendrungan wanita pada usia 30 sampai 40 tahun menyukai sampel minyak jelantah yang ditambahkan 75 gram mengkudu blender.

Untuk Gambar 11 terlihat dari 10 panelis, 30\% menyatakan netral atau biasa, $50 \%$ menyatakan suka dan $20 \%$ menyatakan tidak suka. Terlihat kecendrungan wanita pada usia 30 sampai 40 tahun menyukai sampel minyak jelantah yang ditambahkan 25 gram mengkudu potong.

Untuk Gambar 12 terlihat dari 10 panelis, 20\% menyatakan netral atau biasa, $70 \%$ menyatakan suka dan $10 \%$ menyatakan tidak suka. Terlihat kecendrungan wanita pada usia 30 sampai 40 tahun menyukai sampel minyak jelantah yang ditambahkan 50 gram mengkudu potong.

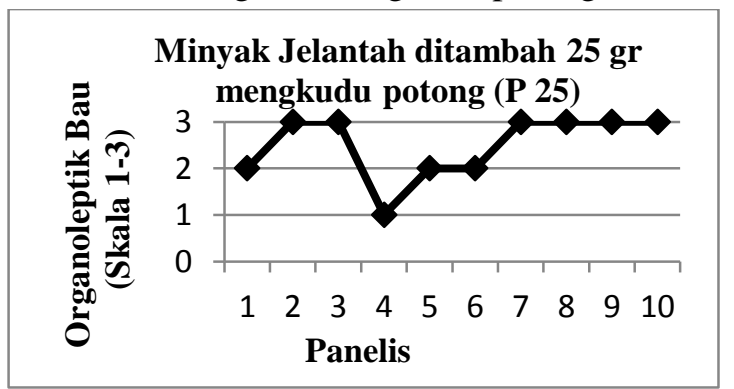

Gambar.11. Organoleptik bau minyak jelantah +25 gr mengkudu potong 


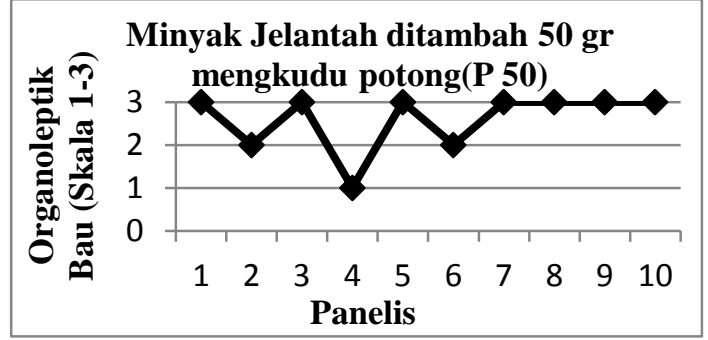

Gambar.12. Organoleptik bau minyak jelantah $+50 \mathrm{gr}$ mengkudu potong

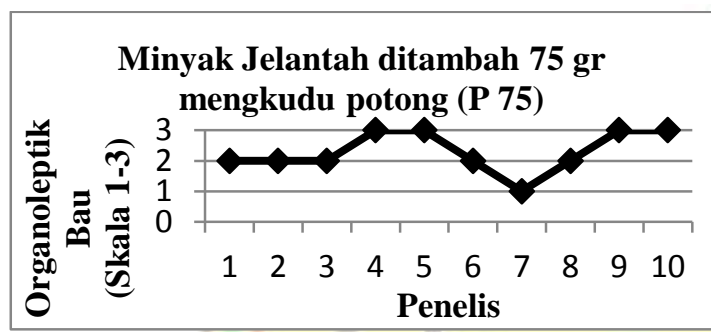

Gambar.13. Organoleptik bau minyak jelantah +75 gr mengkudu potong

Untuk Gambar 13 terlihat dari 10 panelis, 50\% menyatakan netral atau biasa, $40 \%$ menyatakan suka dan $10 \%$ menyatakan tidak suka. Terlihat kecendrungan wanita pada usia 30 sampai 40 tahun menyukai sampel minyak jelantah yang ditambahkan 75 gr mengkudu potong.

\section{Organoleptik Rasa}

Rasa pada bahan pangan hasil olahan dengan cara menggoreng erat kaitan dengan sifat fisik dan kimia dari minyak yang digunakan. Rasa dari bahan pangan dapat disebabkan oleh perombakan kompleks yang dapat menimbulkan rasa sepat [6]. Hasil analisis organoleptik rasa sebelum dan setelah penambahan buah mengkudu dapat dilihat pada Gambar 14 sampai 17. Untuk Gambar 24 terlihat dari 10 panelis, $100 \%$ menyatakan suka untuk sampel A. Hal demikian disebabkan karena minyak kemasan belum dipakai.

Untuk Gambar 15 terlihat dari 10 panelis, 30\% menyatakan netral atau biasa dan $70 \%$ menyatakan tidak suka. Terlihat kecendrungan wanita pada usia 30 sampai 40 tahun tidak menyukai rasa minyak jelantah.

Untuk Gambar 16 terlihat dari 10 panelis, $40 \%$ menyatakan netral atau biasa, $40 \%$ menyatakan suka dan $20 \%$ menyatakan tidak suka. Terlihat kecendrungan wanita pada usia 30 sampai 40 tahun menyatakan netral dan suka untuk sampel minyak jelantah yang ditambahkan 25 gr mengkudu blender.

Untuk Gambar 17 terlihat dari 10 panelis, $60 \%$ menyatakan netral atau biasa, 30\% menyatakan suka dan $10 \%$ menyatakan tidak suka. Terlihat kecendrungan wanita pada usia 30 sampai 40 tahun menilai rasa pada minyak jelantah yang ditambahkan 50 gr mengkudu blender yaitu biasa.

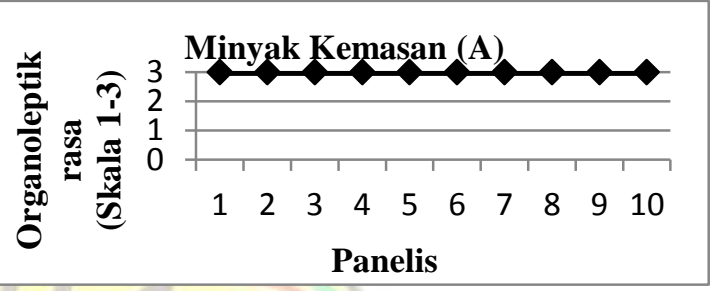

Gambar.14. Organoleptik rasa minyak kemasan

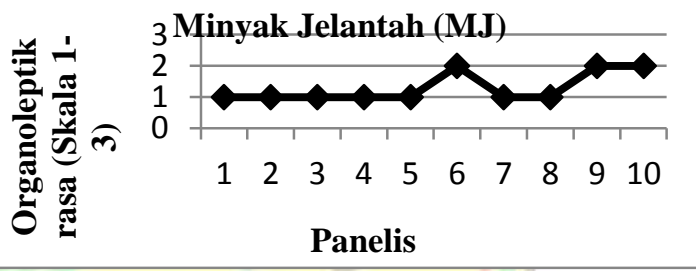

Gambar.15. Organoleptik rasa minyak jelantah

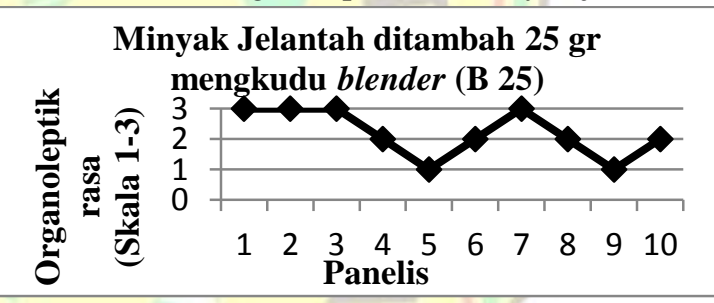

Gambar.16. Organoleptik rasa minyak jelantah +25 gr mengkudu blender

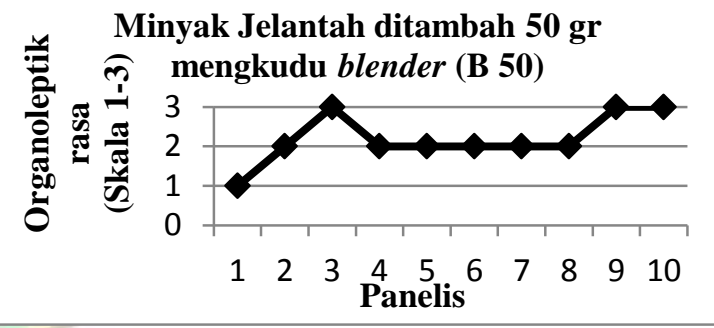

Gambar.17. Organoleptik rasa minyak jelantah +50 gr mengkudu blender

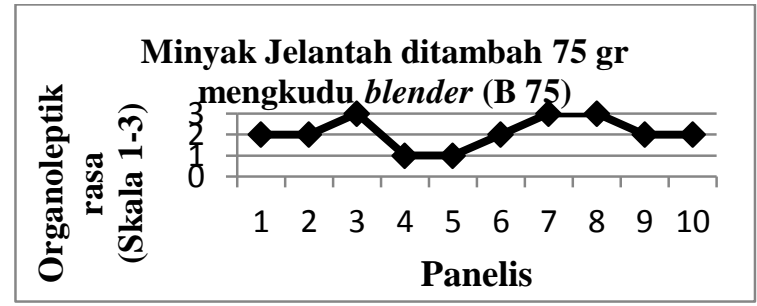

Gambar.18. Organoleptik rasa minyak jelantah +75 gr mengkudu blender 


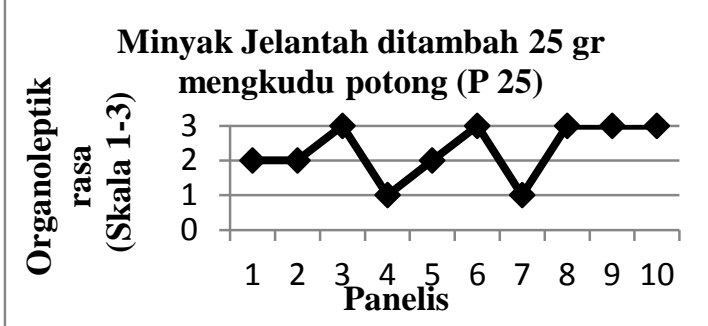

Gambar.19. Organoleptik rasa minyak jelantah +25 gr mengkudu potong

Untuk Gambar 18 terlihat dari 10 panelis 50\% menyatakan netral atau biasa, 30\% menyatakan suka dan $20 \%$ menyatakan tidak suka. Terlihat kecendrungan wanita pada usia 30 sampai 40 tahun menilai rasa pada sampel minyak jelantah yang ditambahkan 75 gr mengkudu blender yaitu biasa.

Untuk Gambar 19 terlihat dari 10 panelis, 30\% menyatakan netral atau biasa, 50\% menyatakan suka dan $20 \%$ menyatakan tidak suka. Terlihat kecendrungan wanita pada usia 30 sampai 40 tahun menyukai sampel minyak jelantah yang ditambahkan 25 gr mengkudu potong.

Untuk Gambar 20 terlihat dari 30 panelis $30 \%$ menyatakan netral atau biasa, $60 \%$ menyatakan suka, dan $10 \%$ menyatakan tidak suka. Terlihat kecendrungan wanita pada usia 30 sampai 40 tahun kecendrungan panelis menyatakan suka untuk sampel minyak jelantah yang ditambahkan $50 \mathrm{gr}$ mengkudu potong.

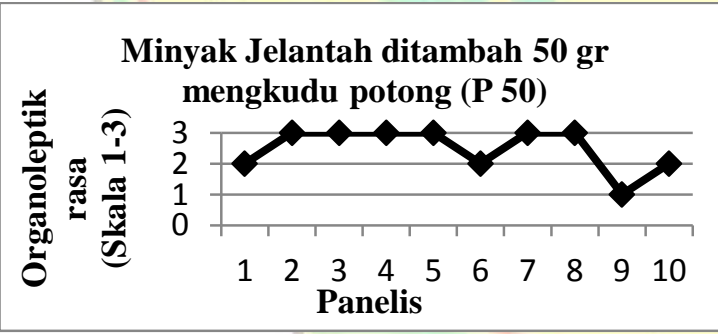

Gambar.20. Organoleptik rasa minyak jelantah + $50 \mathrm{gr}$ mengkudu potong

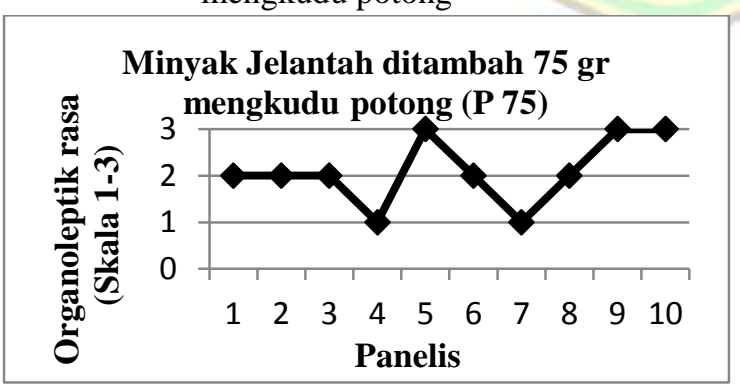

Gambar.21. Organoleptik rasa minyak jelantah $+75 \mathrm{gr}$ mengkudu potong
Untuk Gambar 21 terlihat dari 10 panelis 50\% menyatakan netral atau biasa, 30\% menyatakan suka dan $20 \%$ menyatakan tidak suka. Terlihat kecendrungan wanita pada usia 30 sampai 40 tahun untuk sampel minyak jelantah yang ditambahkan 75 gr mengkudu potong menyatakan netral atau biasa.

\section{KESIMPULAN}

Dari hasil penelitian yang telah dilakukan dapat diambil kesimpulan sebagai berikut:

1. Untuk parameter fisis (viskositas, ORP, konduktivitas, resistivitas) kecenderung masih memiliki nilai viskositas yang sama dengan minyak jelantah. Penambahan buah mengkudu untuk setiap sampel tidak begitu mempengaruhi karakteristik fisis dari minyak jelantah.

2. Untuk sampel minyak jelantah yang ditambahkan buah mengkudu yang diblender mempengaruhi nilai $\mathrm{pH}$ yang signifikan terhadap banyaknya massa dari buah mengkudu, sedangkan untuk nilai sampel minyak jelantah yang ditambahkan buah mengkudu yang dipotong tidak mempengaruhi nilai $\mathrm{pH}$ untuk setiap sampel, tetapi terdapat satu jenis sampel dengan penambahan buah mengkudu potong dengan massa 75 gram memiliki nilai $\mathrm{pH}$ yang lebih tinggi dari pada sampel A dan sampel MJ, mungkin disebabkan oleh pengaruh suhu pada saat pengambilan sampel.

3. Organoleptik rasa dan bau pada minyak jelantah yang ditambah mengkudu potong dan blender menunjukkan kecendrungan panelis lebih menyukai rasa dan bau minyak jelantah yang dimurnikan dengan mengkudu potong.

\section{DAFTAR PUSTAKA}

Hartani, Yustinah. 2011. Adsorbsi Minyak Goreng Bekas Menggunakan Arang Aktif dari Sabut Kelapa. Jurnal Penelitian Teknik Kimia. Hal. $1-2$.

Winarni, dkk. 2010. Penetralan dan Ardsorbsi Minyak Goreng Bekas Menjadi Minyak Goreng Layak Konsumsi. Jurnal Penelitian Jurusan Kimia FMIPA UNNES.Vol. 8 Tanggal 01 Juni 2010. Hal. 46 dan 55. 
Aulia, Afriani, S. Dan Cahyaratri, Febriar. 2005. Pemanfaatan Asam Sitrat sebagai Adsorben

Dalam Upaya Peningkatan Minyak goreng Bekas. Semarang. Jurnal Teknik Kimia Universitas Diponegoro.

Wijayanti, Ria. 2009. Arang Aktif dari Ampas Tebu Sebagai Adsorben Pada Pemurnian Minyak Goreng Bekas. Bogor. Skripsi Depertemen Kimia Fakultas Matematika dan Ilmu Pengetahuan Alam.

www.upi.edu/ Article/Research. Dikunjungi 16

Agustus 2012.
Sutiah, dan F. K. Firdausi. 2008. Studi Kualitas Minyak Goreng dengan Parameter Viskositas dan Indeks Bias. Jurnal FMIPA Vol. 11 No. 2 Hal. 53-58.

Fortuna Dewi ayu dan Hanum Farida Hamzah. 2010. Evaluasi Sifat Fisiko - Kimia Minyak Goreng yang Digunakan Oleh Pedagang Makanan Jajanan di Kecamatan Tampan Kota Pekanbaru. Skripsi Fakultas Pertanian Universitas Riau.Vol 9, No. 1, hal 4 - 1. 